Jurnal IImiah Iqra'

2541-2108 [Online] 1693-5705 [Print]

Tersedia online di: http://journal.iain-manado.ac.id/index.php/J//issue/view/176

\title{
TEORI TRANSFORMASIONAL KEPEMIMPINAN PENDIDIKAN ISLAM
}

\author{
Nurul Sahana \\ Mahasiswa Program Magister MPI UIN Maulana Malik Ibrahim Malang \\ nurulsahana32@gmail.com
}

\begin{abstract}
Abstrak
Pemimpin merupakan posisi paling utama dan bertanggung jawab dalam menentukan organisasi dan menggerakkan anggota organisasinya kearah tujuan yang dicita-citakan. Bukan hanya itu, ketika pemimpin yang lemah dalam menggerakkan organisasinya menjadikan organisasi tersebut terpuruk dan tidak mampu lagi bersaing pada zaman modern.

Pemimpin pendidikan yang ideal harus memiliki kemampuan meyakinkan anggota yang dipimpinnya untuk mewujudkan impian bersama berupa visi organisasinya sehingga layak disebut pemimpin visioner yang mampu melihat jauh kedepan, serta mampu melakukan perubahan-perubahan organisasi berdasarkan analisis-analisis yang cermat dalam kerangka membangun dan mengembangkan mutu institusi pendidikan sehingga dia layak disebut sebagai pemimpin transformasional.
\end{abstract}

Kata kunci: Teori Transformasional, Kepemimpinan Pendidikan Islam

\begin{abstract}
The leader is the most important position and is responsible for determining the organization and moving the members of the organization towards the desired goals. Not only that, when a weak leader in mobilizing his organization makes the organization slumped and unable to compete in modern times.

The ideal education leader must have the ability to convince the members he leads to realize shared dreams in the form of his organizational vision so that he deserves to be called a visionary leader who is able to look far ahead, and is able to make organizational changes based on careful analyzes in the framework of building and developing the quality of educational institutions so he deserves to be called a transformational leader.
\end{abstract}

Keywords: Transformational Theory, Islamic Education Leadership 


\section{Pendahuluan}

Perkembangan zaman, ilmu yang mengkaji tentang organisasi dan kepemimpinan berkembang sesuai dengan perkembangan peradaban manusia. Hal tersebut menjadikan organisasi dituntut untuk menghasilkan produk-produk yang berkualitas dan mampu bersaing pada zaman modern. Hal tersebut dipengaruhi oleh keberhasilan seorang pemimpin dalam mengendalikan dan mengatur organisasinya.

Pemimpin merupakan posisi paling utama dan bertanggung jawab dalam menentukan organisasi dan menggerakkan anggota organisasinya kearah tujuan yang dicita-citakan. Bukan hanya itu, ketika pemimpin yang lemah dalam menggerakkan organisasinya menjadikan organisasi tersebut terpuruk dan tidak mampu lagi bersaing pada zaman modern.

Menyadari hal tersebut, kepala sekolah yang merupakan salah satu contoh pemimpin organisasi dipandang perlu memiliki kecakapan dalam memimpin dan memajukan organisasi pendidikan yang dipimpinnya. Selain itu, tantangan untuk menciptakan mutu pendidikan yang baik menuntut kepala sekolah untuk melakukan pengembangan pendidikan yang terarah, terencana dan berkesinambungan. Kepala sekolah harus memiliki visi dan misi, serta strategi manajemen pendidikan secara utuh dan berorentasi kepada mutu (Mulyasa, 2006).

Oleh karena itu sebenarnya pemimpin pendidikan yang ideal harus memiliki kemampuan meyakinkan anggota yang dipimpinnya untuk mewujudkan impian bersama berupa visi organisasinya sehingga layak disebut pemimpin visioner yang mampu melihat jauh kedepan, serta mampu melakukan perubahan-perubahan organisasi berdasarkan analisis-analisis yang cermat dalam kerangka membangun dan mengembangkan mutu institusi pendidikan sehingga dia layak disebut sebagai pemimpin transformasional (Mulyono, 2009).

Dari latar belakang tersebut, penulis memunculkan makalah yang berjudul “Teori Transformasional Kepemimpinan Pendidikan Islam”.

\section{Kajian Teori}

\section{Pengertian Kepemimpinan Transformasional}

Kepemimpinan transformasional dibangun dari dua kata, yaitu kepemimpinan (leadership) dan transformasional (Transformasional). menurut Terry 
(dalam Kartono) Kepemimpinan adalah aktivitas mempengaruhi orang-orang agar mereka suka berusaha mencapai tujuan-tujuan kelompok (Kartono, n.d.). Menurut Ordway Teod dalam bukunya "The Art Of Leadership" (dalam Kartono), Kepemimpinan merupakan kegiatan mempengaruhi orang-orang bekerja sama untuk mencapai tujuan yang mereka inginkan. Kepemimpinan dapat terjadi dimana saja, asalkan seseorang menunjukkan kemampuannya mempengaruhi perilaku orang lain ke arah tercapainya suatu tujuan tertentu (Kartono, n.d.).

Sedangkan istilah transformasional berasal dari kata "to transform", yang bermakna mentransformasikan atau mengubah sesuatu menjadi bentuk lain yang berbeda. Misalkan mentranformasikan visi menjadi realita, atau mengubah sesuatu yang potensial menjadi aktual (Usman, 2008). Dengan bahasa sederhana dapat didefinisikan bahwa kepemimpinan transformasional ialah proses memimpin yang dapat mengubah individu dalam organisasi untuk mengoptimalkan kinerja dalam rangka memajukan organisasinya.

Model kepemimpinan transformasional adalah model yang komprehensif yang menggunakan pendekatan normatif. Model ini lebih sentralistik, lebih mengarahkan, lebih mengontrol sistem. Model ini cenderung berbuat sewenangwenang karena kepemimpinan yang kuat, berani berkorban sebagai pahlawan, karismatik, dan konsisten dengan teman sejawat dalam berbagai nilai-nilai dan kepentingan-kepentingan umum. Jika model ini berjalan optimal, maka model ini melibatkan stakeholders dalam mencapai tujuan.

Berkaitan dengan kepemimpinan transformasional ini, Leithwood dan kawan-kawan menulis,

"Transformational leadership is seen to be sensitive to organization building, developing shared vision, distributing leadership and building school culture necessary to current restructuring efforts in schools" (Leithwood, Janzi, \& Steinbach, 1999).

Kutipan tersebut menjelaskan bahwa kepemimpinan transformasional mengarahkan SDM kepada kepekaan berorganisasi, pengembangan organisasi, pengembangan visi bersama, pembagian wewenang manajemen dan pembangunan budaya organisasi sekolah dalam rangka penataan kembali sekolah untuk menjadi lebih baik.

Pemimpin transformasional selalu berupaya untuk mengembangkan dan memperbaiki organisasi sesuai dengna kajian pengembangan manajemen dan 
kepemimpinan. Selain itu, pemimpin transformasional selalu berwasawasan jauh ke depan. Tujuan utamanya ialah kemajuan organisasi di masa yang akan datang. Oleh karena itu pemimpin transformasional disebut juga dengan pemimpin yang visioner.

Esensi kepemimpinan transformasional adalah sharing of power dengan melibatkan bawahan secara bersama-sama untuk melakukan perubahan.Dalam meumuskan perubahan biasanya digunakan pendekatan transformasional yang manusiawi, dimana lingkungan kerja yang partisipatif dengan model manajemen yang kolegial yang penuh keterbukan dan keputusan diambil bersama (Usman, 2008).

Dengan demikian kepemimpinan transformasional adalah kepemimpinan yang mampu menciptakan perubahan yang mendasar dan dilandasi oleh nilai-nilai agama, sistem dan budaya untuk menciptakan inovasi dan kreatifitas pengikutnya dalam rangka mencapai visi yang telah ditetapkan (Usman, 2008).

\section{Model Kepemimpinan Transformasional}

Model kepemimpinan transformasional merupakan model yang relatif baru dalam studi-studi kepemimpinan. Burns dalam wikipedia, mengemukakan bahwa untuk memperoleh pemahaman yang lebih baik tentang model kepemimpinan transformasional, model ini perlu dipertentangkan dengan model kepemimpinan transaksional. Kepemimpinan transaksional didasarkan pada otoritas birokrasi dan legitimasi di dalam organisasi. Pemimpin transaksional pada hakekatnya menekankan bahwa seorang pemimpin perlu menentukan apa yang perlu dilakukan para bawahannya untuk mencapai tujuan organisasi.

Bass dan Aviola (dalam Usman) mengusulkan empat dimensi dalam kadar kepemimpinan transformasional dengan konsep "4l" yang artinya (Komariah \& Triatna, 2005):

"|" pertama adalah idealiced influence, yang dijelaskan sebagai perilaku yang menghasilkan rasa hormat (respect) dan rasa percaya diri (trust) dari orang yang dipimpinnya. Idealized influence mengandung makna saling berbagi risiko melalui pertimbangan kebutuhan para staf diatas kebutuhan pribadi dan perilaku moral secara etis.

"|" kedua adalah inspirational motivation, tercermin dalam perilaku yang senantiasa menyediakan tantangan bagi pekerjaan yang dilakukan staf dan memperhatikan makna pekerjaan bagi staf. Pemimpin menunjukkan atau 
mendemonstrasikan komitmen terhadap sasaran organisasi melalui perilaku yang dapat diobservasi staf. Pemimpin adalah seorang motivator yang bersemangat untuk terus membangkitkan antusiasme dan optimisme staf.

"l" ketiga adalah intelelectual stimulation. yaitu pemimpin yang mempraktikan inovasi-inovasi. Sikap dan perilaku kepemimpinannya didasarkan pada ilmu pengetahuan yang berkembang dan secara intelektual mampu menerjemahkannya dalam bentuk kinerja yang produktif. Sebagai intelektual, pemimpin senantiasa menggali ide-ide baru dan solusi yang kreatif dari para staf dan tidak lupa selalu mendorong staf mempelajari dan mempraktikkan pendekatan baru dalam melakukan pekerjaan.

"|" keempat adalah individualized consideration, pemimpin merefleksikan dirinya sebagai seorang yang penuh perhatian dalam mendengarkan dan menindak lanjuti keluhan, ide, harapan-harapan, dan segala masukan yang diberikan staf.

Karisma didefinnisikan sebagai proses seorang pemimpin mempengaruhi pengikutnya dengan emosi-emosi yang kuat sehingga mereka kagum dan segan dengan dirinya. Karisma adalah bagian terpenting dari kepemimpinan transformasional karena para pemimpin transformasional mempengaruhi pengikutnya dengan menimbulkan emosi yang kuat dan identifikasi dengan pemimpin tersebut.

Seorang pemimpin yang memiliki karisma berarti memiliki pengaruh yang bukan didasarkan atas kewenangan, melainkan atas persepsi para pengikut bahwa pemimpin tersebut dikaruniai dengan kemampuan-kemampuan yang luar biasa. Menurut Max Weber, karisma terjadi bila ada suatu krisis sosial sehingga muncul seorang pemimpin dengan kemampuan luar biasa dengan sebuah visi yang radikal yang memberi pemecahan terhadap krisis tersebut (Nurkolis, 2003).

Stimulasi intelektual ialah proses seorang pemimpin untuk meningkatkan kesadaran pengikutnya terhadap masalah-masalah dan mempengaruhi pengikutnya untuk memecahkan masalah-masalah itu dengan perspektif yang baru.

Perhatian yang diindividualisasi ialah dukungan, membesarkan hati, dan memberikan pengalaman-pengalaman kepada pengikutnya untuk lebih berprestasi (Usman, 2008).

Kepemimpinan transformasional dapat dipandang secara makro dan mikro. Jika dipandang secara mikro kepemimpinan transformasional merupakan proses 
mempengaruhi antar individu, sementara secara makro merupakan proses memobilisasi kekuatan untuk mengubah sistem sosial dan mereformasi kelembagaan (Komariah \& Triatna, 2005).

Jadi dalam prosesnya, pemimpim transformasional dipandang mampu memberikan pengaruh kepada anggotanya untuk mengembangkan organisasi yang dipimpinnya dengan daya dukung kemampuan pribadi yang baik, pemikiran akan masa depan organisasinya dan juga emosi-emosi serta kemampuan lainnya dalam rangka untuk mempengaruhi anggotanya.

\section{Ciri-ciri Kepemimpinan Transformasional}

Dalam kehidupan berorganisasi, bukan hanya sistem yang memilki pengaruh besar pada efektivitas dan efisiensi organisasi. Tapi juga bagaimana gaya kepimipinan seorang pemimpin juga memiliki pengaruh besar dalam menumbuh kembangkan organisasi yang dipimpinnya.

Model kepemimpinan transformasional selalu menekankan pada proses untuk menggerakkan para anggotanya untuk orientasi masa depan organisasi. Model inilah yang diterapkan dalam lingkungan pendidikan untuk kebutuhan menanamkan budaya inovasi dan kreatifitas dalam meningkatkan kreativitas dalam meningkatkan mutu dan eksistensi institusi pendidikan. Hal ini penting karena warga institusi pendidikan terutama peserta didik berharap banyak untuk terciptanya institusi pendidikan yang berkualitas, produktif serta profesional dalam menapaki masa depan dan segala tantangan yang ada.

Adapun ciri-ciri dari pemimpin transformasional menurut Luthans dalam Danim diantaranya: 1) Mengidentifikasi dirinya sebagai agen perubahan, 2) Memiliki sifat pemberani, 3) Mempercayai orang lain, 4) Bertindak atas dasar sistem nilai (bukan atas dasar kepentingan individu), 5) Meningkatkan kemampuannya secara terus- menerus, 6) Memiliki kemampuan untuk menghadapi situasi yang rumit, tidak jelas dan tidak menentu, 7) Memiliki visi ke depan (Danim \& Dkk, 2009).

Selain ciri-ciri tersebut, ciri-ciri lain dari pemimpin transformasional yang dimunculkan oleh Wuradji, antara lain: 1) Memiliki keberanian untuk melakukan perubahan menuju tingkat produktivitas yang lebih tinggi, 2) Mampu membangkitkan semangat dan motivasi pengikutnya untuk bekerja keras, 3) Mampu mengembangkan semangat kebersamaan, disiplin dan motivasi untuk maju, 4) Mampu membangun kesadaran berorganisasi pada para pengikutnya, dengan 
jalan mengembangkan rasa memiliki organisasi (sense of belonging), dan rasa bertanggung jawab (sense of responsibility) serta membangun kemauan untuk meraih prestasi yang setinggi- tingginya, 5) Mampu memberikan perlindungan (mengayomi) dan menciptakan rasa aman dikalangan pengikutnya, 6) Menggunakan kemampuan intelektualnya secara cerdas dalam proses pengambilan keputusan, 7) Mampu menampung dan menangkap semua aspirasi dan kepentingan pengikutnya, 8) Memperjuangkan kebutuhan pengikutnya, 9) Memberikan pengarahan yang selalu diterima dan dipatuhi dengan ikhlas, 10) sehingga pengikutnya memiliki rasa wajib untuk mentaati semua perintah dan arahannya, 12) Berusaha membawa pengikutnya ke arah suatu idealisme, tidak hanya sekedar asal jalan, dan dapat meyakinkan pengikutnya bahwa apa yang dicitacitakannya (idealisme) tersebut pasti akan tercapai, 13) Pemimpin menempatkan diri sebagai agen perubahan (Wuradji, 2009).

Dengan berdasar pada beberapa ciri-ciri yang dikemukakan oleh kedua ahli, maka ciri-ciri yang dimiliki oleh pemimpin transformasional menurut Yukl dalam Mulyono antara lain: 1) Mampu mendorong pengikut untuk menyadari pentingnya hasil pekerjaan, 2) Mendorong pengikut untuk lebih mendahulukan kepentingan organisasi, 3) Mendorong untuk mencapai kebutuhan yang lebih tinggi (Mulyono, 2009).

Dari beberapa ciri-ciri yang dikemukakan oleh para ahli, kepemimpinan transformasional merupakan model kepemimpinan yang berusaha untuk semaksimal mungkin dalam memajukan organisasinya. Dengan memperhitungkan dampak baik dan buruknya, seorang pemimpin dituntut bukan hanya terampil dalam memimpin, memajukan organisasinya serta memikirkan masa depan organisasinya, tapi juga dituntut untuk mampu meningkatkan kemampuan yang dimiliki anggotanya. Sehingga selain organisasinya yang baik, anggotanya juga terampil dalam mengemban tugasnya dan juga mampu menempati jabatan-jabatan yang lebih tinggi dari sebelumnya.

Selain itu, kemampuan individu yang dimiliki seorang pemimpin dengan model ini, dapat mempengaruhi diri sendiri untuk membangun self direction (mengatur diri sendiri), dengan pengendalian diri dan self motivation (memotivasi diri sendiri) untuk berperilaku proaktif dan kreatif serta bersedia menghukum diri atas kesalahan yang dibuat dan berkinerja sesuai yang diinginkan. 


\section{Kepemimpinan Transformasional dalam Pendidikan Agama Islam}

Kepemimpinan pendidikan merupakan bagian esensial dari suatu organisasi pendidikan, bahkan merupakan hal yang sangat urgen dalam berjalannya organisasi pendidikan untuk mencapai tujuan pendidikan yang bersifat institusional maupun nasional (Baharuddin \& Umiarso, 2002).

"Ingatlah ketika Tuhanmu berfirman kepada Para Malaikat: "Sesungguhnya aku hendak menjadikan seorang khalifah di muka bumi." mereka berkata: "Mengapa Engkau hendak menjadikan (khalifah) di bumi itu orang yang akan membuat kerusakan padanya dan menumpahkan darah, Padahal Kami Senantiasa bertasbih dengan memuji Engkau dan mensucikan Engkau?" Tuhan berfirman: "Sesungguhnya aku mengetahui apa yang tidak kamu ketahui (Agama, 2012)."

Ayat tersebut menunjukan bahwa manusia memang dikonsep oleh Tuhan sebagai pemimpin (khalifah) yang mengatur serta mengelola bumi. Dimana model dan proses kepemimpinannya berlandaskan pada al-Quran dan mencontoh sifat yang dicontohkan oleh Rasulullah. Sifat tersebut antara lain siddiq, amanah, tabligh dan fathanah. Keempat sifat tersebut yang melandasi seorang pemimpin dalam bersikap dalam organisasi yang dipimpinnya. Termasuk di dalamnya menentukan arah serta tujuan organisasi di masa yang akan datang.

Secara umum, konsep kepemimpinan dalam Islam sebenarnya memiliki dasar-dasar yang sangat kuat dan kokoh. la dibangun tidak saja oleh nilai-nilai transcendental, namun telah dipraktikkan sejak berabad-abad yang lalu oleh Nabi Muhammad SAW, para sahabat, dan al-Khulafa' al-Rasyidin. Pijakan kuat yang bersumber dari Al Qur'an dan Sunnah serta dengan bukti empiriknya telah menempatkan konsep kepemimpinan dalam Islam sebagai salah satu model kepemimpinan yang diakui dan dikagumi oleh dunia internasional (Baharuddin \& Umiarso, 2002).

Selain itu, yang dinamakan pemimpin adalah mereka yang mampu mempengaruhi orang lain yang menjadi anggotanya. Kepemimpinan tersebut dapat diartikan sebagai kemauan mengarahkan pengikut-pengikutnya untuk bekerja bersama dengan kepercayaan serta tekun mengerjakan tugas-tugas yang diberikan oleh pimpinan mereka.

Kepemimpinan memiliki hubungan yang multi-dimensional dan kompleks. Di dalamnya tercakup pemimpin, pengikut-pengikutnya, dan situasi yang tercipta oleh tugas-tugas organisasi, nilai-nilai sosial, kondisi ekonomi, fasilitas teknologi dan 
pertimbangan-pertimbangan politis. Hasil riset terakhir mengungkapkan bahwa kepemimpinan yang sukses membutuhkan suatu situasi tertentu. Pengembangan keterampilan-keterampilan berikut ini juga penting:

Objektivitas terhadap hubungan dan perilaku manusia. Seorang pemimpin harus mampu melihat orang-orang dan perilaku mereka secara obyektif dan tidak emosional. la tidak boleh memiliki kebiasaan berprasangka. Untuk setiap tindakan yang penting, ia harus mampu mengidentifikasi pengaruh-pengaruh dan responsi. Pemimpin tersebut harus memiliki kemampuan untuk menentukan sebab-sebab dari timbulnya response dan mampu meniliti kesimpulan-kesimpulan.

Mampu berkomunikasi, yakni Pemimpin harus mampu berbicara dan menulis dengan tegas dan secara cermat membuat ringkasan dari pernyataan-pernyataan orang lain. Lagi pula, ia harus dapat didekati, mengenal kelompok dan pemimpin informal mereka, memberitahukan tujuan kerjanya dan berusaha bekerja sama dengan rekan-rekannya.

Wibawa, yaitu Kemampuan untuk memproyeksi posisi pengikutnya sesuai mental dan emosi mereka, membantu pemimpin tersebut untuk mengikuti pandangan, keyakinan dan tindakan-tindakan pengikutnya. Wibawa menghasilkan rasa hormat, walaupun orang lain mungkin tidak menyetujui keyakinan dan nilai-nilai pandangannya.

Kesadaran diri, di mana Pemimpin tersebut mengetahui kesan-kesan yang diberikan oleh orang lain. la harus berusaha untuk memenuhi peranan sebagaimana diharapkan oleh pengikut-pengikutnya.

Mengajar, Yakni Cara terbaik untuk memimpin, mengembangkan dan menginspirasi kepada orang lain ialah dengan cara mengajarkan kepada mereka halhal yang perlu mereka ketahui. la harus menggunakan keterampilannya melalui demonstrasi dan memberi contoh-sontoh soal (Terry, n.d.).

\section{Kesimpulan}

Dari pembahasan yang menjawab rumusan masalah tersebut, maka diperoleh jawaban sebagai berikut:

Pertama, Kepemimpinan transformasional adalah kepemimpinan yang mampu menciptakan perubahan yang mendasar dan dilandasi oleh nilai-nilai agama, 
sistem dan budaya untuk menciptakan inovasi dan kreatifitas pengikutnya dalam rangka mencapai visi yang telah ditetapkan.

Kedua, Model kepemimpinan transformasional terkonsep dalam "4l" yang dikemukakan oleh Bass dan Aviola antara lain: 1) influence, yang dijelaskan sebagai perilaku yang menghasilkan rasa hormat; 2) inspirational motivation, tercermin dalam perilaku yang senantiasa menyediakan tantangan bagi pekerjaan; 3) intelelectual stimulation. yaitu pemimpin yang mempraktikan inovasi-inovasi; 4) individualized consideration, pemimpin merefleksikan dirinya sebagai seorang yang penuh perhatian.

Ciri-ciri yang dimiliki oleh pemimpin transformasional yang dikemukakan oleh Yukl dalam Mulyono antara lain: 1) Mampu mendorong pengikut untuk menyadari pentingnya hasil pekerjaan; 2) Mendorong pengikut untuk lebih mendahulukan kepentingan organisasi; 3) Mendorong untuk mencapai kebutuhan yang lebih tinggi.

Peranan sifat Rasulullah (siddiq, amanah, tabligh dan fathanah) memberikan peranan untuk melandasi seorang pemimpin transformasional dalam bersikap dalam organisasi yang dipimpinnya. Termasuk di dalamnya menentukan arah serta tujuan organisasi di masa yang akan datang.

\section{Referensi}

Agama, K. (2012). Al-Qur'an dan Terjemahnya. Jakarta: PT. Sinergi Pustaka Indonesia.

Baharuddin, \& Umiarso. (2002). Kepemimpinan Pendidikan Islam. Yogyakarta: ArRuzz Media.

Danim, S., \& Dkk. (2009). Manajamen dan Kepemipinan Transformasional Kepala sekolahan. Jakarta: Rineka Cipta.

Kartono, K. (n.d.). Pemimpin dan Kepemimpinan. Jakarta: Rajawali Press.

Komariah, A., \& Triatna, C. (2005). Visionary Leadership Menuju Sekolah Efektif. Jakarta: P.T. Bumi Aksara.

Leithwood, Janzi, \& Steinbach. (1999). Changing Leadership for Changing Times. Buckingham: Open University Press.

Mulyasa. (2006). Menjadi Kepala Sekolah Profesional. Bandung: Remaja Rosda Karya. 
Mulyono. (2009). Educational Leadership; Mewujudkan Efektivitas Kepemimpinan Pendidikan. Malang: UIN Malang Press.

Nurkolis. (2003). Manajemen Berbasis Sekolah. Jakarta: Gramedia Widiasarana Indonesia.

Terry, G. R. (n.d.). Prinsip-Prinsip Manajemen. Jakarta: Bumi Aksara.

Usman, H. (2008). Manajemen ,Teori Praktik dan Riset Pendidikan. Jakarta: Bumi Aksara.

Wuradji. (2009). The Educational Leadership (Kepemimpinan Transformasional). Yogyakarta: Gama Media. 